\title{
The status and conservation of threatened and near-threatened species of birds in the Red River Delta, Vietnam
}

\author{
ANITA PEDERSEN, SANNE SCHNELL NIELSEN, LE DIEN THUY and \\ LE TRONG TRAI
}

\section{Summary}

The Red River Delta in northern Vietnam is an important stopover and wintering site for migratory waterbirds. During the spring of 1994, six globally threatened and five near-threatened species were observed in the coastal areas of the Delta. According to current applications of threat categories, one of the species has Critical status (Black-faced Spoonbill Platalea minor), three are Endangered (Nordmann's Greenshank Tringa guttifer, Saunders's Gull Larus saundersi and Chinese Egret Egretta eulophotes), two are Vulnerable (Spoonbill Sandpiper Eurynorhynchus pygmaeus and Spot-billed Pelican Pelecanus philippensis) and five are Near-threatened (Asian Dowitcher Limnodromus semipalmatus, Grey-headed Lapwing Vanellus cinereus, Black-headed Ibis Threskiornis melanocephalus, Painted Stork Mycteria leucocephala and Japanese Paradise-Flycatcher Terpsiphone atrocaudata). A nature reserve, also listed as a Ramsar area, already exists in the middle of the Delta. The Cua Day Estuary in the southern part of the delta is not included in either the nature reserve or Ramsar area. However, observations of 260 Saunders's Gulls and 41 Black-faced Spoonbills, which represent $9 \%$ and $12 \%$ of the estimated respective world populations, indicates the international importance of this area. The major threats to the waterbirds using the delta are reclamation of intertidal sand- and mudflats for aquaculture, increased disturbance associated with collection of sea products and hunting. Recommendations are made for future conservation actions.

\section{Introduction}

The Red River originates in the Van Nam highlands in China and flows for about $1,300 \mathrm{~km}$ before it debouches in the Gulf of Tonkin. The total catchment area has been estimated as $169,000 \mathrm{~km}^{2}$, of which $82,400 \mathrm{~km}^{2}$ lies in China and the rest drains northern Vietnam (Anon. 1995). The Red River plain or the delta itself covers c. 17,000 km² (Roop et al. 1994; Anon. 1995). In the coastal areas of the delta, average population density is 1 ,0oo persons per $\mathrm{km}^{2}$ (de Vylder 1991). Most people living in the Delta are rice farmers who for years have supplemented their income and daily food intake by exploiting the natural resources in the intertidal area.

At low tide in the coastal area of the Red River Delta, huge areas consisting of sand- and mudflats are exposed. The intertidal area continually increases in size through the deposition of silt from the large rivers. Both erosion and accretion take place, the latter being the more dominant of the two processes. This has 
resulted in a seawards expansion of the sand- and mudflats. In recent years thousands of hectares of productive intertidal areas and extensive areas of mangrove have been converted into crab and shrimp ponds or lost due to land reclamation. This conversion is caused by poverty, increasing population and rising pressure from economic development.

In 1986, Vietnam launched an economic reform process known as doi moi which encouraged privatization and included a liberal foreign investment law. This economic reform resulted in rapid economic growth which unfortunately has contributed to an unsustainable use of natural resources in the coastal zone, resulting in degradation of natural habitats. The collection of birds, fish and other marine products has increased significantly because the new economic policy allowed such products to be exported to China.

No long-term surveys have been conducted in the delta before and only sporadic information exists on the waterbird populations. In 1988, a brief survey was conducted in the middle of the delta in Xuan Thuy, which was then identified as a wetland of international importance according to the Ramsar criteria (Scott et al. 1989). Vietnam joined the Ramsar Convention in September 1988 and the Xuan Thuy Nature Reserve was the first to be listed.

A combined study of birds, molluscs and use of natural resources was conducted from February to June 1994 in the southern part of the Red River Delta in the Cua Day Estuary (Figure 1). Due to the knowledge and protection of the Xuan Thuy Nature Reserve, the present survey focused on the Cua Day Estuary. The aim of the study was to provide baseline information to be used in the planning of conservation and sustainable use of resources in the Red River Delta.

This paper includes all observations of threatened and near-threatened species of birds made during the present survey, a summary of earlier records from Vietnam and an updated review. Recommendations for future protection of these species in the delta are suggested. A conservation management report for the Cua Day Estuary and studies of birds, molluscs and resources-use will be published elsewhere.

\section{Study area}

Waterbird counts were conducted at three localities in the Red River Delta in the Cua Day Estuary: Nghia Hung District ( $\left.19^{\circ} 57^{\prime} \mathrm{N} 106^{\circ} \mathrm{g}^{\prime} \mathrm{E}\right)$, in the Xuan Thuy Nature Reserve, Xuan Thuy District $\left(20^{\circ} 16^{\prime} \mathrm{N} 106^{\circ} 34^{\prime} \mathrm{E}\right)$, both in Nam Ha Province and in the Van Uc Estuary, Tien Lang District $\left(20^{\circ} 39^{\prime} \mathrm{N} 106^{\circ} 41^{\prime} \mathrm{E}\right)$, Hai Phong City (Figure 1 ).

The principal study area was the Cua Day Estuary in the southern part of the delta. The area encompasses $c .75 \mathrm{~km}^{2}$ and borders the Phu Loi Canal to the north, the Gulf of Tonkin to the south, the Day River to the west, and the Nincho River to the east. The estuary can be divided into two major zones: land within (c. $40 \mathrm{~km}^{2}$ ) and land beyond $\left(\right.$ c. $35 \mathrm{~km}^{2}$ ) the main dike.

Land has been reclaimed inside the main dike for many years (Anon. 1995). Aquaculture with crab and shrimp ponds has been established just inside the main dike. The land behind the aquaculture area comprises paddy rice-fields, 


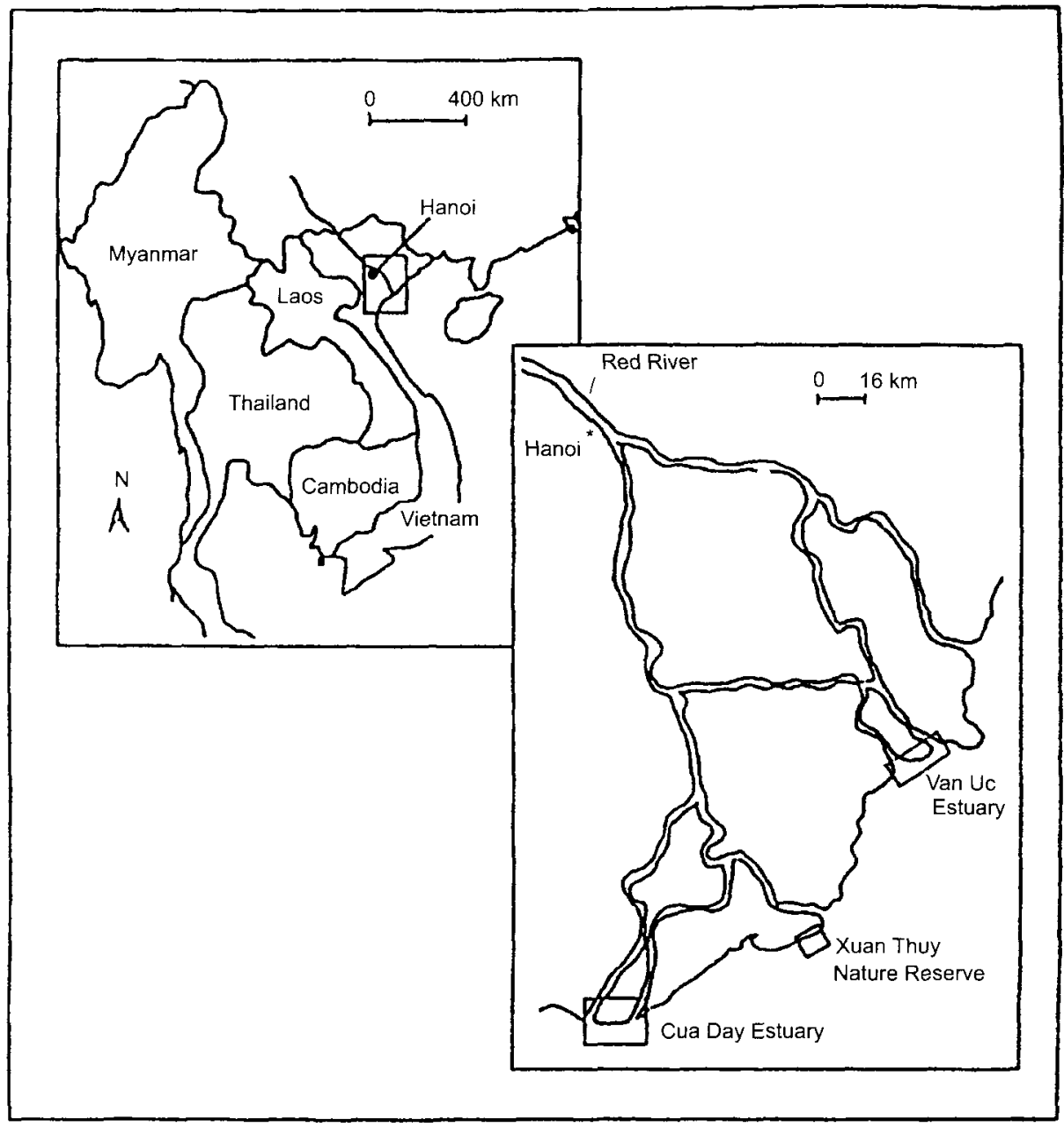

Figure 1. Location of Cua Day Estuary, Xuan Thuy Nature Reserve and Van Uc Estuary, Red River Delta, Vietnam.

networks of channels and human settlements. The area outside the main dike consists of a large intertidal area with sand- and mudflats, mangrove, sandy beaches and the island, Con Mo. Previously the coastline was completely fringed by mangroves. During the last decades, the mangroves have been totally destroyed by local people for firewood and reclamation of land. In 1986 local authorities began planting mangroves in the Cua Day Estuary. Thus, in $1994 \mathrm{C}$. $11 \mathrm{~km}^{2}$ of mudflats were covered with mangroves and most of the trees were $0.5^{-1.5 \mathrm{~m} \text { tall. }}$

In the delta there is only one tide cycle per day. During the survey period, the high tide was about one hour later each day and around neap tide period there was an 11 hour phase shift. The maximum tidal range was $c .3 .4 \mathrm{~m}$ at spring tides and c. $2.0 \mathrm{~m}$ at neap tides (Anon. 1993b). 


\section{Methods}

Daily counts were carried out in the Cua Day Estuary only interrupted by comparative counts once per month in the Xuan Thuy Nature Reserve. One visit was made to the northern part of the delta in the Van Uc Estuary on 31 March2 April.

Total counts, supplemented with line transects, were used to cover these large areas. Counts were normally carried out by the project team on foot, bicycle or by boat. Due to the huge area of intertidal flats exposed during low tide, high-tide counts were the primary method used when estimating the numbers of shorebirds in the intertidal area. Based on the amplitude of the tides and the single daily tide cycle, high-tide counts could only be conducted over a few days once every two weeks. Three high-tide roosts were identified in the Cua Day Estuary and at least two were visited during every high-tide period. Total coverage of shorebirds using the intertidal area in the Cua Day Estuary was obtained through these high tide counts. At low tide, counts were made using line transects at the dikes in the rice-field areas and in the intertidal area. Line transects were divided in 200-m wide sections as this was found to be optimal. The total length of the transects was $c .35 \mathrm{~km}$. Total coverage of the larger waterbirds is assumed to be obtained only in the paddy rice-field and pond areas. The taxonomic treatment in this paper follows Sibley and Monroe (1990) and the threat categories are according to Collar et al. (1994).

\section{Observations and status of threatened and near-threatened species}

Detailed below are records of all bird species assigned an IUCN category of threat plus those considered to be near-threatened after Collar et al. (1994), which were recorded during this survey.

Present survey During the survey, Nordmann's Greenshank was only observed from 21 to 30 April (Table 1). A single individual in winter plumage was seen on 21 April foraging together with five Marsh Sandpipers Tringa stagnatilis and three Common Greenshanks Tringa nebularia at low tide on an intertidal mudflat close to the mangrove. Two birds in winter plumage were seen on 24 April roosting among 1,300 shorebirds (including 750 Spotted Redshanks Tringa erythropus, 150 Common Redshanks Tringa totanus, 100 Marsh Sandpipers and 210 Common Greenshanks). Their size were noticeably smaller than the Spotted Redshanks, although more round and bulky. Their bills were thicker than those of the Common Greenshank. The parti-coloured bill, as shown in Hayman et al. (1986), was not a useful identification feature as some birds had an uni-coloured bill (cf. Kennerley and Bakewell 1986, 1991). The legs of the Nordmann's Greenshanks were distinctly shorter than those of the Common Greenshanks. A bird seen on 25 April was in winter plumage roosting on a sand dune together with 300 shorebirds comprising to different species, including 210 Grey-tailed Tattlers Tringa brevipes. From 27 to 29 April, up to five birds were recorded in the Xuan Thuy Nature Reserve. Only one bird was in breeding plumage. It had 


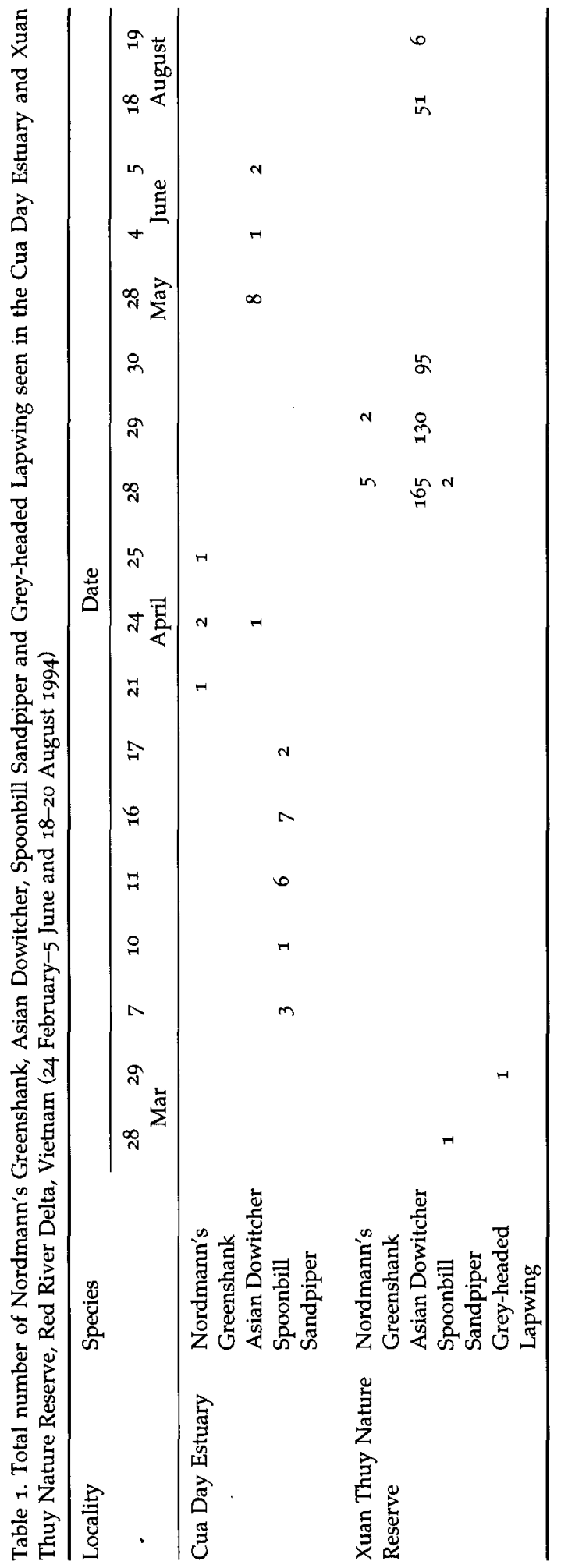


distinct spots on its breast and a parti-coloured bill. Five birds were seen on 28 April standing together and sleeping at high-tide roost in the periphery of a group of 900 shorebirds (including 650 Common Redshanks) in the Xuan Thuy Nature Reserve. The following day, two birds, both in winter plumage, were seen roosting in the same place in a mixed group of shorebirds.

Previous records from Vietnam The first record from Vietnam was on 27 March 1989 when one individual was observed in the Xuan Thuy Nature Reserve (Scott et al. 1989). Two birds were subsequently seen between 20 March and 9 April 1991 (Lane et al. 1994).

Review Total world population of the Nordmann's Greenshank is estimated at c. 1,000 individuals and the species is considered Endangered (Collar et al. 1994). For further comments on the status, see Collar et al. (1994).

Present survey The first observation of the Asian Dowitcher was of one individual in breeding plumage in the Cua Day Estuary, during a high-tide count on 24 April (Table 1). It was roosting in a mixed flock of 1,300 shorebirds most of them Tringa sandpipers. As the water was rising, they were forced out of the mangrove and up to a nearby raised sandflat where they were seen feeding together with 50 Black-tailed Godwits Limosa limosa in a dense flock. During the survey the peak spring migration through the Red River Delta was at the end of April (Table 1 ) when up to 165 birds were registered by this survey in the Xuan Thuy Nature Reserve. This is the highest number ever recorded in Vietnam. Up until the end of this survey in early June, very small numbers could still be seen in the Cua Day Estuary.

During the visit to the Xuan Thuy Nature Reserve on 18-20 August, up to 51 birds were seen at a high-tide roost. The birds were seen roosting in a mixed group together with 153 Black-tailed Godwits.

Previous records from Vietnam The Asian Dowitcher has been classified as rare in the Red Data Book of Vietnam (Anon. 1992). The first documented record in Vietnam appears to be one individual in Hue in September 1925 (Delacour and Jabouille 1931). The next record is from Minh Hai Province in the Mekong Delta where 22 were seen in November 1980 (Fisher 1983). These are the only autumn records. There have been several spring observations during the last couple of years. In 1988, three Asian Dowitchers were recorded in March in the Xuan Thuy Nature Reserve (Scott 1989) while six birds were seen in May in the Gianh River Estuary, Quang Binh Province (Robson et al. 1989, J. Eames, verbally 1996). During a short survey conducted in March 1989 in the Xuan Thuy Nature Reserve, 13 birds were observed on 27 March and eight were observed on 28 March (Scott et al. 1989).

Review The population of the Asian Dowitcher has been estimated at 15,00020,000 individuals (Rose and Scott 1994). It is classified as Near-threatened by 
Collar et al. (1994), in contrast to the classification as globally threatened in the IUCN Red List (Groombridge 1993). For further comments on the status, see Perennou et al. (1994).

Spoonbill Sandpiper Eurynorhynchus pygmeus

VULNERABLE

Present survey Observations of the Spoonbill Sandpiper were made from 28 March to 28 April (Table 1 ). The peak in spring migration appeared to take place in mid-April when seven birds were seen in the Cua Day Estuary. During spring passage, all birds were seen in mixed species groups with Rufous-necked Stints Calidris ruficollis and a few Sanderlings C. alba.

The birds seen on 28 March, 7 April and 16-17 April were foraging on sandy intertidal flats in shallow water $(1-3 \mathrm{~cm})$. The Spoonbill Sandpipers were seen walking slowly forward, sweeping their heads from side to side and sometimes turning around their axis still with heads down. The other observations of Spoonbill Sandpiper were made during a high-tide roost with other Calidris species.

Previous records from Vietnam The first published record of the Spoonbill Sandpiper is from 1991 when one bird was observed on 1-2 April in the Xuan Thuy Nature Reserve (Lane et al. 1994). However, D. A. Scott (in litt. 1995) saw one bird at this location already on 30 April 1990. Furthermore, local hunters reported having caught these birds in small numbers in the Xuan Thuy Nature Reserve (Scott et al. 1989) and in the Cua Day Estuary (Anon. 1993a).

According to information forms filled in by local hunters $(92 / 93$ by Centre for National Resources Management and Environmental Studies (CRES), Hanoi University), 35 Spoonbill Sandpiper were reported caught: two in November 1992, six in January 1993, 12 in February 1993, 11 in March 1993 and four in April 1993 (Le Dien Duc 1993b). This information seems dubious, however, since local hunters told us that the birds only appear in the delta during April-May. However, winter records are known from Hong Kong in 1992 and 1993 (Carey 1993b, 1994).

Review The global population of the Spoonbill Sandpiper has been estimated at 4,000-6,000 birds (Rose and Scott 1994), and the species has been classified as Vulnerable (Collar et al. 1994). For further comments on the status, see Collar et al. (1994).

Present survey One individual was seen 29 March in the Xuan Thuy Nature Reserve, roosting in mangrove (Table $\mathbf{1}$ ).

Previous records from Vietnam There are a few older observations of Grey-headed Lapwings from northern Vietnam (Delacour and Jabouille 1931, Fischer 1983, Robson et al. 1989) and the species has previously only been reported in the Xuan Thuy Nature Reserve where two birds were seen in March 1989 (Scott et al. 
1989). From southern Vietnam, it has been reported regularly (e.g. Wildash 1968, Perennou et al. 1990, Perennou and Mundkhur 1992). In Ha Tinh Province, central Vietnam, up to 500 birds were reported during the winter of 1990 - one of the highest number hitherto known at a wintering site (Robson 1990).

Review No well-supported population estimate exists of this species although it is believed to have declined to fewer than 25,000 individuals (Perennou et al. 1994). The species is classified as Near-threatened (Collar et al. 1994). For further comments on the status, see Perennou et al. (1994).

Present survey The Saunders's Gull was only observed in the Cua Day Estuary in the delta. The first observation took place on 3 March around sunset when 260 birds came in from the sea, flying inland. They flew in a dense group making noisy tern-like calls. On 9 March, several observations were made. Six birds were seen roosting in the mudflat area. From $16 \mathrm{~h} 30$ until sunset a total of 108 Saunders's Gulls were seen evening migrating north-east along the coast line, passing in small groups of 2-38 individuals, some of them together with Herring Gulls Larus argentatus and Common Black-headed Gulls $L$. ridibundus. Most of the Saunders's Gulls were adults in breeding plumage with full black hoods and only a few birds were immatures. Up to 31 birds were seen on 12-16 March foraging in small groups with Common Black-headed Gulls on the sand- and mudflats. Saunders's Gulls were on several occasions observed eating crabs on the mudflat. Having caught a crab, the gull ascended several metres into the air dropped the crab, repeating this process until it finally ate the crab. The last observation was two birds on 18 March as they were flying south in the late afternoon.

Previous records from Vietnam The first record of Saunders's Gull from Vietnam is early March 1988 in the Xuan Thuy Nature Reserve where more than 200 birds were observed (Scott 1989, Scott et al. 1989). The following year at the end of March, 2-4 birds were recorded, also in the Xuan Thuy Nature Reserve (Scott $e t$ al. 1989). These few observations would justify the status as rare in the Red Data Book of Vietnam (Anon. 1992). Based on the present and the previous surveys in the Xuan Thuy Nature Reserve during 1988 (Scott et al. 1989, Scott 1989), it would seem that the Red River Delta is a very important wintering area for Saunders's Gull.

Review The population has been estimated at 3,000 individuals (Rose and Scott 1994), and the species is classified as Endangered (Collar et al. 1994). For further comments on the status, see Collar et al. (1994).

Present survey This species was recorded only in the Cua Day Estuary. The first record comprised one individual in winter plumage seen on 24 March feeding 
in the rice-fields together with Little Egrets Egretta garzetta, Great Egrets Casmerodius albus, Intermediate Egrets Mesophoyx intermedia and Cattle Egrets Bubulcus ibis.

Two individuals in breeding plumage were seen feeding in shallow water on an intertidal mudflat on 6 April. On 6 and 10 April a solitary individual in winter plumage was observed feeding in paddyfields. The last observation was of one individual in breeding plumage on 25 May feeding very actively along the tideline.

Previous records from Vietnam The first known record of Chinese Egret in Vietnam is from the Xuan Thuy Nature Reserve where one individual was recorded in March 1988 (Scott 1989). The following year on 28 March, two individuals were seen in the same place (Scott et al. 1989). In mid-April 1991, eight birds were seen in Cam Ranh Bay, southern Vietnam (Eames et al. 1992). The last known record is from the Cua Day Estuary where up to 1o birds were seen on 7-8 April 1993 (Anon. 1993a).

Review The global population of the Chinese Egret has been estimated at 2,500 individuals (Rose and Scott 1994), and the species is classified as Endangered (Collar et al. 1994). For further comments on the status, see Collar et al. (1994).

Present survey Two observations were made of this species during the survey in the delta: On 25 February, a single immature bird was seen flying inland at sunset together with 25 Great Egrets Casmerodius albus. Eight adults were seen feeding on a mudflat in the Van Uc Estuary on 31 March.

Previous records from Vietnam The Black-headed Ibis has been reported on a few occasions in northern (Fischer 1961, 1974) and central Vietnam (Delacour and Jabouille 1925, 1931), and it is said to have been common in southern Vietnam (Delacour and Jabouille 1925, 1931, Wildash 1968). Records of 10,000 individuals are known from the Mekong Delta (Krapowiez 1985) where small breeding colonies are also reported to occur (del Hoyo et al. 1992).

Review The population of the Black-headed Ibis in South-East Asia has been estimated at 10,000-25,000 individuals, and it is classified as Near-Threatened (Collar et al. 1994). For further comments on the status, see del Hoyo et al. (1992).

Present survey The Black-faced Spoonbill was regularly seen during the present survey (Table 2). Most birds were seen foraging in shallow intertidal channels or at the mangrove edge. In $78 \%$ of the cases, foraging birds were seen close to the mangrove edge, where a high density of Tellina sp. (a bivalve) and gastropods occurred. The survey showed that the main roosting area in the delta was the Cua Day Estuary (Table 2) with records of up to 41 individuals, $12 \%$ of the estimated world population. 
Anita Pedersen et al.

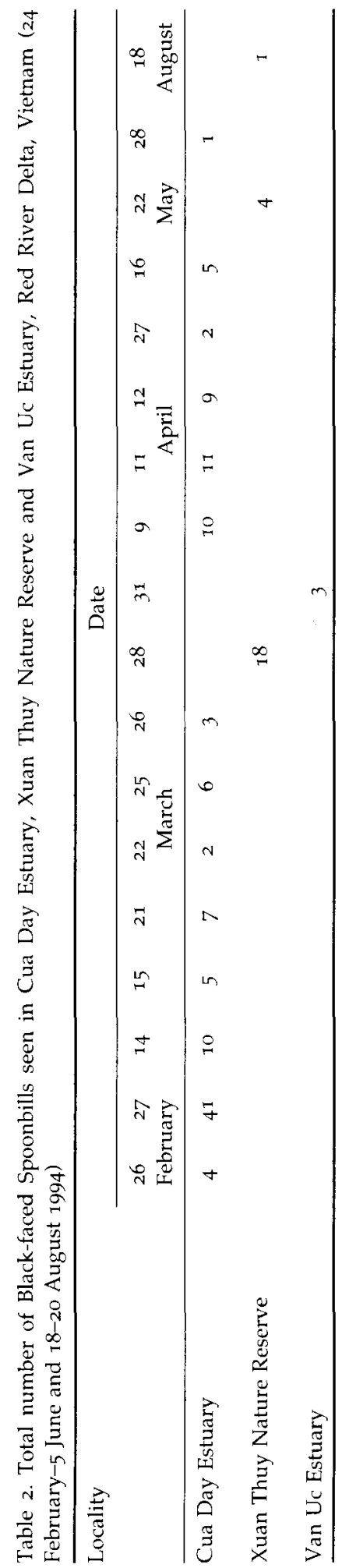


Owing to a lack of a total count covering the entire coastal zone of the delta, and because only a small part of the delta was visited regularly, it is not known if more than those $\mathbf{4 1}$ individuals were present. It is likely that a higher number could have existed, even for a long time, judging from the presence of other suitable roosting and feeding areas.

During the visit to the northern part of the delta in the Van Uc Estuary (Figure 1) in March 1994, three birds were seen roosting on intertidal mudflats (Table 2). No previous records of Black-faced Spoonbills have been reported from the Van Uc Estuary. During the short visit in August to the Xuan Thuy Nature Reserve, one individual (Table 2) was seen roosting together with a group of 30 Painted Storks Mycteria leucocephala. This bird was probably oversummering in the area, a phenomenon also known from Hong Kong.

Previous records from Vietnam Numerous records exist from all over Vietnam. Probably the first published account (Delacour 1929) mentions it as accidental in central Vietnam during winter and with even fewer records in the south. However, a recent observation has occurred of a single bird at Tram Chim Nature Reserve on 4 January 1994 (J. Eames, verbally 1994). Most published observations are from the Tonkin area in northern Vietnam, where the possible first records are from 1961 (Fischer 1961) and 1963 (Fischer 1974). The Black-faced Spoonbill is classified as rare in the Red Data Book of Vietnam (Anon. 1992).

Since the late 1980 , there have been almost annual records from the Red River Delta (Table 3). Counts have shown that the Xuan Thuy Nature Reserve is an important wintering area for Black-faced Spoonbills with records of up to 68 individuals in January 1993 (Le Dien Duc et al. 1993). It seems that the birds regularly use the delta from January to May (Table 3), but due to the absence of any midwinter data it is not known how long they stay. There are only records of Black-faced Spoonbills in the southern part of the delta in the Cua Day Estuary from 1992 and 1993, mainly because this area has not previously been visited.

Table 3. Monthly peak observations from known studies of the Black-faced Spoonbill in the Red River Delta, Vietnam from 1987 to 1994. Observations appear from the Cua Day Estuary 1993-1994, Xuan Thuy Nature Reserve 1987-1994 and Van Uc Estuary 1994

\begin{tabular}{|c|c|c|c|c|c|c|c|c|c|}
\hline \multirow[t]{2}{*}{ Month } & \multicolumn{9}{|c|}{ Year } \\
\hline & 1987 & 1988 & 1989 & 1992 & 1993 & & 1994 & & \\
\hline January & & *a & & & $68^{\mathrm{a}}$ & & & & \\
\hline February & & ${ }^{*} 62^{a}$ & & & & & & $41^{b}$ & \\
\hline March & & $32^{a}$ & $27^{\circ}$ & & $2^{a}$ & $2^{b}$ & $18^{\mathrm{a}}$ & $10^{b}$ & $3^{c}$ \\
\hline April & $60^{a}$ & & & & $5^{\text {a }}$ & $28^{b}$ & & $11^{b}$ & \\
\hline May & & & & & $2^{a}$ & & $4^{a}$ & $5^{b}$ & \\
\hline August & & & & & & & $I^{a}$ & & \\
\hline November & & & & $24^{a}$ & & $25^{b}$ & & & \\
\hline
\end{tabular}

a Xuan Thuy Nature Reserve, b Cua Day Estuary, ' Van Uc Estuary. * Reference states early 1988. Data compiled from Scott 1989, Scott et al. 1989, Anon. 1993a, Le Dien Duc et al. 1993a, Dahmer and Felley 1994, CRES, unpublished, and present survey. 
Review The Black-faced Spoonbill is one of the world's most endangered species, with Critical status (Collar et al. 1994). Based on counts and estimates during the winter of 1993-1994, the world population is estimated at 341 individuals (Dahmer and Felley 1994). This corresponds closely to Rose and Scott's (1994) estimate of 350 individuals. Dahmer and Felley's (1994) estimate from Vietnam is based on the occurrence of 25 individuals in the Red River Delta in November 1993. The present record of 41 birds raises the importance of the Red River Delta for this species. For further comments on the status, see Collar et al. (1994).

Present survey Four Spot-billed Pelicans were recorded in the Cua Day Estuary on 4-5 June 1994. As no counts were made in June in other parts of the delta, it is not known whether the species appeared elsewhere. The four individuals were mostly seen swimming, feeding alone or in groups beyond the deeper intertidal channel. They were only registered in the most remote part of the intertidal area near the Cua Day River. During a short visit to Xuan Thuy Nature Reserve, two Spot-billed Pelicans were seen on 18 August 1994 and five the following day. These birds were recorded at high tide on remote sand-flats together with gulls and shorebirds.

Previous records from Vietnam The Red Data Book of Vietnam classifies the Spot-billed Pelican as rare (Anon. 1992). In Vietnam, the first known record of the Spot-billed Pelican was from January 1923 when an immature was recorded from Annam, central Vietnam. According to locals, it was then a casual visitor (Delacour and Jabouille 1925). Later, Delacour and Jabouille (1931) and Wildash (1968) mention it only as occurring in southern Vietnam. The first observation from the Red River Delta was August 1964 when six Spot-billed Pelicans were observed on the main outflow of the Red River (in Xuan Thuy Nature Reserve?) (Fischer 1974). A group of 32 birds was seen flying over central Hanoi on 1 July 1981 (Stusak and Vo Quy, 1986). Fischer $(1963,1974)$ also mentions the possibility of a small breeding colony (40 pairs) in the Cua Day Estuary near the sea. During a survey in the Xuan Thuy Nature Reserve in 1988 and in the Cua Day Estuary in 1993, local fishermen reported regular occurrence of small flocks of pelicans (Scott et al. 1989, Anon. 1993a). The pelicans were recorded as staying in the Delta especially in November and December (Scott 1989), but according to Le Dien Duc (1993a) the pelicans were only seen in August.

Review The population of Spot-billed Pelican has been estimated at 10,000 individuals in southern Asia and at 1,500 individuals in South-East Asia (Rose and Scott 1994), and the species is classified as Vulnerable (Collar et al. 1994).

In the winter of 1992 the Tonle Sap Lake in Cambodia was located as the probable main wintering area in South-East Asia with records of 1,250 individuals (Perennou et al. 1994). For further comments on the status, see Collar et al. (1994). 
Present survey During the present survey Painted Storks were observed in the Xuan Thuy Nature Reserve on 18-20 August. Thirty birds were seen roosting together with one Black-faced Spoonbill at the mangrove edge. Reserve staff had never seen a Painted Stork so it was probably the first occurrence of this species in the area in recent years.

Previous records from Vietnam There is only one previous observation from the Red River Delta, concerning three birds seen in July 1964 (Fischer 1974). Previously, the Painted Stork was common in most of Indochina (Delacour and Jabouille 1931). Over the years, the number of observations have declined, and according to Sibley and Monroe (1990) this species does not appear in northern Vietnam although it still occurs in the rest of Indochina. Several observation have been made in recent years in southern Vietnam: in Nam Bai Cat Tien (Eames et al. 1992), a group of 20 birds at Duyen Hai Province, Mekong Delta 9 September 1993, and a group of 92 birds at Tram Chim Nature Reserve 4 January 1995 (J. Eames, verbally 1996). According to the Red Data Book of Vietnam, it is now classified as rare occurring only in the south (Anon. 1992). Tram Chim Nature Reserve in southern Vietnam has, according to the Asian Waterfowl census of 1987-1991, been identified as the area with highest mid-winter concentrations (Perennou et al. 1994).

Review The Painted Stork is classified as Near-threatened (Collar et al. 1994). It is widespread throughout southern Asia with an estimated population of 15,000 individuals (Perennou et al. 1994). For further comments on the status, see del Hoyo et al. (1992).

Present survey One male was seen roosting on 23 April in a forest on a small island in the Cua Day Estuary.

Previous records from Vietnam The species is a migrant in Indochina. Nevertheless, there are only two published records from Vietnam (Delacour and Jabouille 1931, Wildash 1968). The species has also been recorded in early April 1994 when a bird was recorded in Hanoi (J. Eames, verbally 1994).

Review The Japanese Paradise-Flycatcher is classified as Near-Threatened (Collar et al. 1994). For further comments on the status, see Sibley and Monroe (1990).

\section{Threats}

In the Red River Delta, three main types of threat were identified which reduced the value of the area to waterbirds. They include reclamation of the intertidal area for ponds, disturbance from collection of marine products and intensive hunting. 


\section{Reclamation of land}

Reclamation of the intertidal area in the Red River Delta has taken place for years. The great increase in human population in this century, and the resulting shortage of land for agriculture, has led to increased pressure on natural resources. The large demand for food production has resulted in vast areas of intertidal flats being allocated for agricultural purposes and mangroves being logged for firewood and charcoal production.

Recently, an indiscriminate, and very rapid allocation of sand- and mudflats and mangrove for crab and shrimp ponds took place in the entire delta. This constitutes the greatest threat to the ecosystem and, of course, also to the globally threatened species. Previous experience with such ponds is that they often produced a very low yield after two to three years due to lack of advice and investment. This decrease in yield resulted in the construction of new ponds rather than the improvement of the conditions in the existing ones.

The mangrove and adjacent mudflats are extremely productive and are a major source of food for people, birds, etc. The destruction of the intertidal area is unsustainable as it reduces vitally important breeding and nursery grounds for many species of fish and crustacean, which make up an important part of inshore and marine fisheries. The mangrove forests also constitute an important source of timber, firewood and other important products such as honey. Furthermore, the mangrove forest plays a vital role in coastal protection and thus in the long-term build up of arable land.

\section{Collection of marine products}

Birds were rarely observed feeding on the sand- and mudflats of the Red River Delta at low tide. This absence was probably caused by disturbance from the people collecting crabs and molluscs in the intertidal area. During the main collecting season from February to June in the Cua Day Estuary, more than 1,300 people use the intertidal area every day during low tide. Nearly $100 \%$ of the families living closest to the coastline are directly or indirectly employed in mollusc or crab exploitation. We estimated that 830 tonnes of molluscs and crabs were collected from the intertidal area at Cua Day Estuary during this study period (S.S.N. et al. unpublished).

It was easy to observe the effect of the disturbance on more visible birds such as Spot-billed Pelicans, Black-faced Spoonbills and egrets/herons. These birds only occurred in very remote parts of the intertidal area visited by few people.

The most threatened species in the delta, the Black-faced Spoonbill, was mostly seen foraging in areas with few people and high densities of Tellina sp. and gastropods. Annually, 800 tonnes of Tellina sp. are collected by locals and used for feeding domestic ducks and crabs cultivated in the ponds (S.S.N. et al. unpublished).

\section{Hunting}

The catching of migratory birds in the Red River Delta has been a tradition for generations. The most common hunting technique is mist-nests made of synthetic 
fibre. In the intertidal area (c. $35 \mathrm{~km} 2)$ in the Cua Day Estuary, a total of $17.5 \mathrm{~km}$ of mist-nets was in use in February 1994. Thus the level of hunting appeared to be very high. The majority of hunters were mostly interested in catching ducks and geese and during the migratory period shorebirds were mostly taken. The locals earn US\$ 1 per day on average and hunting is a very attractive extra source of income. One goose may generate US\$ 15 and one duck US $\$ 3-4$ if sold for export to China. Most larger waterbirds may be sold for export to China and the smaller ones, e.g. shorebirds, may be sold on the local market for US\$ 0.5 per bird. Other species caught in the mist-nets are regarded as incidental catch by most people, although some people do eat small birds such as swallows, flycatchers, etc.. Approximately 600 birds (34 species) were observed caught during the present survey but this represents only a small fraction of the total catch. Hunting levels are likely to be quite intense, judging by the fact that almost no resident birds are found in the coastal area (S.S.N. and A.P. unpublished).

All species of birds are captured indiscriminately, including threatened and near-threatened species. According to data collected by Le Dien Duc (1993b), Black-faced Spoonbills and Spoonbill Sandpipers have been captured. Such information was confirmed during the present survey together with information on previous catches of pelicans. Hunters did not appear to be particularly interested in the Black-faced Spoonbills and Spot-billed Pelicans, but during the autumn, egrets and herons are captured using glue. These birds are exported to China and at the time of the survey it was not known whether Black-faced Spoonbills or Chinese Egrets were mingled with the egrets and herons.

Hunting regulations exist in the delta but are not respected. In the Xuan Thuy Nature Reserve, established in 1988, hunting is prohibited although catching still takes place. In the Cua Day Estuary, a ban was introduced in 1993 without much effect because of a failure to inform the public, and a failure by the police to enforce the law.

\section{Discussion}

The Red River Delta is very important to the threatened and near-threatened species using the delta. Black-faced Spoonbills and Saunders's Gulls apparently use the area for a long time during winter. To other threatened and near-threatened species, the delta seems to be situated on the East Asian or Australasian flyway (Pedersen et al. 1996), and is used as a stopover site for shorter or longer periods depending on weather conditions, disturbance, etc. The East Asian or Australasian flyway is one of the major waterbird migration pathways of the world, involving 4-6 million shorebirds and an unknown number of herons, ducks, geese and other waterbirds (Parish 1989). The majority of these birds migrate from breeding grounds in eastern Siberia, China, Korea and Japan to non-breeding areas in subtropical and tropical parts of the region and as far away as Australia. Wetlands are very important for the migratory species but these habitats are subject to threats of destruction from rapid economic development and extensive exploitation of natural resources (Lane and Parish 1991).

All globally threatened birds in the Red River Delta have very limited distribution and quite restricted breeding ranges which make them vulnerable. 
For the Black-faced Spoonbill, breeding sites are known only sporadically and any protection is therefore necessarily incomplete. Egg collection and hunting occur on the breeding grounds. For the Nordmann's Greenshank and Saunders's Gull, the main reason for declining populations is destruction of their breeding habitats caused by development projects (Nechaev 1989, Carey 1993a).

However, improved protection of the globally threatened birds can not be obtained solely by focusing on their breeding areas. During migration, these birds become even more restricted in their distribution as they follow narrow migration corridors with a few staging areas. Attention must therefore also be paid to the sites where they occur during non-breeding periods. International cooperation is needed to secure a network of protected zones along the migratory flyway throughout the region so as to ensure future protection of the populations of migratory and threatened birds.

Most threats to migratory waterbirds are anthropogenic (Moser 1991). The main threats at many important wintering sites for such species as the Black-faced Spoonbill and the Saunders's Gull are wetland reclamation and coastal development. Due to the new economic reform process in Vietnam, the number of ponds, and thereby the demand for feed, are expected to rise in the future. Unfortunately, the main collecting season of marine products coincides with the wintering period of the Black-faced Spoonbill. Tellina sp. are known to be part of the diet for the Eurasian Spoonbill Platalea leucorodia (Cramp 1977) but it is not known if the Tellina sp. is also important for Black-faced Spoonbills or if people and Black-faced Spoonbill consequently compete. In Hong Kong, disturbance from fishermen and collectors has been observed to prevent Black-faced Spoonbills from feeding during low tide (del Hoyo et al. 1992).

Detailed ecological studies have demonstrated that migratory waterbirds aggregate in the best feeding areas (e.g. Goss-Custard et al. 1977) and that this takes place on several spatial scales. This enables the birds to accumulate the fat reserves needed for long-distance flight (Lane and Parish 1991). Mangroves and associated mudflats are very important for migratory shorebirds during migration and during winter (Howes 1989). Human disturbance such as shellfish collection can be a significant problem for migratory birds concentrating in large numbers in one place to feed or roost. Repeated disturbance may prevent the birds from feeding and thus prevent them from getting enough food and thereby diminishing their chances of survival (Biber and Salathé 1991).

\section{Conservation and sustainable development}

High population density, the population's need for natural resources, and the resulting impact on the natural ecosystems must be considered in the development of any conservation plan. Conservation efforts may be made more effective by addressing the diverse socio-economic problems which cause pressure on the wetlands. Conservation of migratory birds in the Red River Delta can only be achieved through a broad-based approach for management of the natural habitats where trade-offs between expansion of agriculture, crab and shrimp pond farming, exploitation of molluscs, coastal fishery and long-term coastal development are considered. Previous experiences from other South-East Asian countries indicate that proper management of resources can avoid conflict 
and ensure long-term sustainability of mangrove ecosystems (Ruitenbeek 1994).

In the future, one of the first steps will be to make local people aware of the distinction between short-term and long-term (sustainable) values of an ecosystem. Campaigns should be launched to raise awareness of the values, functions and the importance of retaining the mangrove forest and the sand-and mudflats. Educational material is needed for information on the ecology of the delta, for a better understanding of the effects of the destruction of the intertidal area and the unsustainable use of marine products, birds, etc. It will be particulary difficult to convince the locals about the advantage of a long-term moderate/stable income compared with a short-term high income. To make long-term benefits realistic, economic resources and expert advice are needed to establish alternative incomes so that over-exploitation of natural resources may be avoided. Furthermore, conditions in existing ponds will have to be improved so that their extension can be minimized and the intertidal habitat can be preserved.

It seems very probable that the bird populations are over-exploited in the Cua Day Estuary, but because of insufficient data no firm conclusion can be drawn. As for future protection of the migratory waterbirds and the threatened birds using the delta, a realistic strategy which is easy to understand and administer will have to be implemented. The most realistic approach may be the introduction of alternative means of income which will have to be more profitable than hunting. In addition, hunters need to be convinced of the advantage of exploiting the area in ways that ensure long-term benefits and sustainable use. Even though alternative incomes may be generated, introduction of a total hunting ban is regarded as unrealistic as hunting is a tradition-bound activity that has existed for generations. It may be more realistic to implement some hunting regulations that will provide long-term advantages to the hunters.

Some hunting regulations are unrealistic for protection of specific threatened birds because the main hunting technique is mist-netting which is non-selective. The Nordmann's Greenshank and the Asian Dowitcher and other shorebirds should be regarded as "look-alike species" in this respect. Hunters can see no difference, and to them all "longlegged shorebirds" are lumped in one category, "tiêu, tiêu". Closing of the hunting season for periods is administratively unrealistic because the intertidal area is too extensive to be controlled and hunting with nets often takes place during nights with no moon. The best solution would probably be to establish a network of many small protected areas.

Such protected areas should be established as a network of hunting- and disturbance-free zones so that the birds always may move to quiet areas if disturbed. In Denmark, such a network of hunting- and disturbance-free zones has already been established. Based on this network, it has been proved that human activities, including hunting (shooting), angling and rambling have great disturbing effects on migratory waterbirds. In experimental areas, it was seen that the number of waterbirds remained below the potential capacity of food resources and resting possibilities. After the establishment of protected areas the total number of birds using the adjacent areas has increased (e.g. Madsen 1993).

There is political will to establish protected areas in the delta. The authorities have expressed an interest in expansion of the nature reserve in Xuan Thuy. The main reason is the potential for ecotourism in the area as an incentive for 
protection of nature. One of the reasons for the establishment of the nature reserve in Xuan Thuy was the occurrence of Black-faced Spoonbill. The Black-faced Spoonbill is now used as a symbol for the existing nature reserve and it has thereby become a tool for nature conservation in Xuan Thuy. The Black-faced Spoonbill was a good choice for this purpose because it is a conspicuous bird, known by hunters, fishermen and children. In future awareness campaigns, it would obviously make sense to use a bird known by the locals, such as Black-faced Spoonbill, Spot-bill Pelican or Spoonbill Sandpiper.

The management and administration of a conservation plan for the Cua Day Estuary could be conducted by establishing a Ramsar area or a nature reserve under Vietnamese law. The observations made in this survey of $9 \%$ and $12 \%$ of the estimated world population of Saunders's Gull and Black-faced Spoonbill respectively qualify the area as a Ramsar site based on the $1 \%$ criterion. Since the Ramsar Convention considers wetland conservation as an integral part of socio-economic development, there will be more benefits to the local people by establishing a Ramsar area because of the options for training and technology transfer under the Ramsar Convention. Because a Ramsar area has no legal status under Vietnamese law, it is important for full protection to ensure that the area first obtains status as a nature reserve.

\section{Conclusion}

It is a realistic prospect to protect the globally threatened and near-threatened species in the Red River Delta but it will be a long-term process. There is an urgent need to draw up a conservation plan which may use the concept of sustainable development in order to integrate socio-economic development with conservation of wildlife in this area.

\section{Acknowledgements}

We would like to thank the staff of the Ministry of Agriculture and Rural Development (the former Ministry of Forestry), Vietnam: the Minister, Mr Nguyen Quang Ha, the staff of Forest Inventory and Planning Institute (FIPI), especially Mr Vu Van Dung, Mr Nguyen Huu Dong, Mr Le Sau and Mr Vo Tri Chung; The People's Committees in the delta; the people in Nghia Hung District; the staff of Xuan Thuy Nature Reserve; Jonathan Eames, BirdLife Vietnam Programme; David Hulse, WWF Vietnam Programme; Institute of Ecology and Biological Resources (IEBR), National Centre for Scientific Research; Centre for Natural Resources management and Environmental Studies (CRES), University of Hanoi; Zoological Museum, University of Copenhagen; Mr Derek A. Scott and our interpreters Truong Dieu Que and Do Lan Huong. We sincerely thank Jon Fjeldså, Zoological Museum, University of Copenhagen, for his advice and valuable suggestions during the whole project period and for his comments on this manuscript. The project was funded by Asian Wetland Bureau; Carlsen-Langes Legatsstiftelse; COWIconsult; DAFIF-DOF, BirdLife Denmark; Torben og Alice Frimodts Fond; Frimodt-Heineke Fonden; Oriental Bird Club; Plums Økologi Fond and Zoological Museum, University of Copenhagen.

\section{References}

Anon. (1992) Sach Do Viet Nam. Phan Dong Vat. Red data book of Vietnam, 1. Animals. Ministry of Science, Technology and Environment. Hanoi: Science and Technics Publishing House. (In Vietnamese.) 
Anon. (1993a) Cua Day proposed conservation and development project, Vietnam. Identification report. Unpubl. BirdLife-Sweden, BirdLife-Denmark and NORDECO.

Anon. (1993b) Bang Thuy Trieu 1994. Tap 1. (Tide Tables 1994, 1) Hydrometeorological service. Hanoi: Trung Tam Khi Tuong Thuy Van Bien Xuat Ban.

Anon. (1995) Red River Delta master plan, 1. Summary. (VIE/89/034) Minsitry of Science, Technology and Environment, Vietnam in association with UNDP and the World Bank.

Biber, J-P. and Salathé, T. (1991) Threats to migratory birds. Pp. $17-35$ in T. Salathé, ed. Conserving migratory birds. Cambridge, U.K.: International Council for Bird Preservation (Techn. Publ. 12).

Carey, G. (1993a) Saunders' Gull: heading for extinction? Orient. Bird Club Bull. 17: 14.

Carey, G. J., ed. (1993b) The Hong Kong bird report 1992. Hong Kong: Hong Kong Birdwatching Society.

Carey, G. J., ed. (1994) The Hong Kong bird report 1993. Hong Kong: Hong Kong Birdwatching Society.

Chalmers, M. L. (1986) Annotated checklist of the birds of Hong Kong, fourth edition. Hong Kong: Hong Kong Birdwatching Society.

Collar, N. J., Crosby, M. J. and Stattersfield, A. J. (1994) Birds to watch 2: The world list of threatened birds. Cambridge, U.K.: BirdLife International (BirdLife Conserv. Series 4).

Cramp, S. (1977) Handbook of the birds of the western Palearctic, 1. Oxford: Oxford University Press.

Dahmer, T. D. and Felly, M. L. (1994) Census and population status of Black-faced Spoonbills during winter 1993-1994. Hong Kong Bird Rep. 1993: 177-183.

Delacour, J. (1929) Les oiseaux migrateurs de I'Indochine Française. J. Om. 71-82.

Delacour, J. and Jabouille, P. (1925) On the birds of Quangtri, Central Annam; with notes on others from other parts of French Indo-China. Ibis 12: 209-260.

Delacour, J. and Jabouille, P. (1931) Les oiseaux de l'Indochine Française. Paris: Exposition Coloniale Internationale.

del Hoyo, J., Elliott, A. and Sargatal, J., eds. (1992) Handbook of the birds of the world, 1. Barcelona: Lynx Editions.

de Vylder, S. (1991) Situations- og perspektivanalyse Vietnam. Denmark DANIDA, Ministry of Foreign Affairs. (In Danish.)

Eames, J. C., Robson, C. R., Nguyen Cu and Truong Van La (1992) Vietnam forest project. Forest bird surveys 1991. Cambridge, U.K.: International Council for Bird Preservation (Study Rep. 51).

Fischer, W. (1961) Kleine Beiträge sur Vogelkunde Vietnams. Beitr. Vogelk. 7: 285-317.

Fischer, W. (1963) Weitere Beiträge sur Vogelkunde Vietnams. -Beitr. Vogelk. 9: 102-123.

Fischer, W. (1974) Vorläufiger Abschlussbericht über Vogelbeobachtungen in Vietnam. Beitr. Vogelkd. 20: 249-300.

Fischer, W. F. (1983) Ein beitrag zum Voerkommen, Durchzug und zur Übersommerung von Limikolen (Charadriiformes) in Vietnam. Beitr. Vogelkd. 29: 297-305.

Goss-Custard, J. D., Kay, D. G. and Blindell, R. M. (1977) The density of migratory and overwintering Redshank, Tringa totamus (L.) and Curlew, Numenius arquata (L.), in relation to the density of their prey in south-east england. Est. Coastal Mar. Sci. 5: 497510 .

Groombridge, B., ed. (1993) 1994 IUCN red list of threatened animals. Gland, Switzerland: IUCN.

Hayman, P., Marchant, J. and Prater, T. (1986) Shorebirds: an identification guide to the waders of the world. London: Christopher Helm.

Howes, J. P. (1989) The importance of intertidal wetlands in Sarawak for conservation of migratory shorebirds. In D. Parish and R. C. Prentice, eds. Wetland and waterfowl conservation in Asia. Kuala Lumpur: Asian Wetland Bureau/International Waterfowl Research Bureau. 
Kennerley, P. R. and Bakewell, D. N. (1986) Nordmann's Greenshank in Hong Kong: a review of the identification and status. Pp. 83-100 in The Hong Kong bird report 1985. Hong Kong: Hong Kong Birdwatching Society.

Kennerley, P. R. and Bakewell, D. N. (1991) Identification and status of Nordmann's Greenshank. Dutch Birding 13: 1-8.

Krapowiez, Z. (1985) Wetlands in East Asia: a preliminary review and inventory. Cambridge, U.K.: International Council for Bird Preservation (Study Rep. 6, pp. 166168).

Lane, B. and Parish, D. (1991) A review of the Asian-Australasian bird migration system. Pp. 291-312 in T. Salathé, ed. Conserving migratory birds. Cambridge, U.K.: International Council for Bird Preservation (Techn. Publ, 12).

Lane, B. A., Naismith, L., Starks, J. R., Le Dien Duc and Barter, M. A. (1994) Shorebirds at Xuan Thuy Reserve, Red River Delta, Vietnam in March/April 1991. Melbourne: Australasian Wader Studies Group; Hanoi: University of Hanoi and Kuala Lumpur: Asian Wetland Bureau (AWB Publication 103).

Le Dien Doc (1993a) Wetland's reserves in Vietnam. Centre for Natural Resources Management and Environmental Studies (CRES), University of Hanoi. Hanoi: Agricultural Publishing House.

Le Dien Doc (1993b) Final report on monitoring of hunting pressure on waterbirds on the Red River Delta, Vietnam. Kaula Lumpur: Asian Wetland Bureau (AWB-project, LEDD/92).

Le Dien Doc, Le Dinh Thuy and Hoang Van Thang (1993) Black-faced Spoonbills in the North of Viet Nam 1992-1993. Specialist Group on Storks, Ibises and Spoonbills Neusletter $6(1 / 2): 8-9$.

Madsen, J. (1993) Experimental wildlife reserves in Denmark: a summary of results. Wader Study Group Bull. 68: 23-28.

Moser, M. E. (1991) Priorities for the conservation of migratory waterfowl. Pp. 361-374 in T. Salathé, ed. Conserving migratory birds. Cambridge, U.K.: International Council for Bird Preservation (Techn. Publ. 12).

Nechaev, V. A. (1989) The status of Nordmann's Greenshank (Tringa guttifer) in the USSR. Asian Wetland News 2(2): 11-14.

Parish, D. (1989) Population estimates of water birds using the East Asian/Australasian flyway. Pp. 8-13 in H. Boyd and J-Y. Pirot, eds. Flyways and reserve networks for water birds. Slimbridge, U.K.: International Waterfowl Research Bureau (Special publ. 9).

Pedersen, A., Nielsen, S. S., Le Dinh Thuy and Le Trong Trai (1996) Northward migration of shorebirds through the Red River Delta, Vietnam, in 1994. Stilt 28: 22-31.

Perennou, C. and Mundkhur, T. (1992) Asian water fowl census 1992. Slimbridge, U.K.: International Waterfowl Research Bureau.

Perennou, C., Rose, P. and Poole, C. (1990) Asian water fowl census 1990. Slimbridge, U.K.: International Waterfowl Research Bureau.

Perennou, C., Mundkhur, T., Scott, D. A., Follestad, A. and Kvenild, L. (1994) The Asian waterfowl census 1987-91: distribution and status of Asian waterfowl. Kuala Lumpur: Asian Wetland Bureau (AWB publ. 86) and Slimbridge, U.K.: International Waterfowl Research Bureau (Publ. 24).

Robson, C. (1990) Recent reports. India, Indonesia, Nepal, Thailand and Viet Nam. Orient. Bird Club Bull. 12: 40-44.

Robson, C. R., Eames, J. C., Wolstencroft, J. A., Nguyen Cu and Trung Van La (1989) Recent records of birds from Viet Nam. Forktail 5: 71-97.

Roop, J. A., Bansgrove, A. J., England, S. J., Sinh, N. N. and Thang, H. C., eds. (1994) State of the coastal and marine environment report, Viet Nam, 1994. Vancouver, Canada: ESSA Technologies.

Rose, P. M. and Scott, D. A. (1994) Waterfowl population estimates. Slimbridge, U.K.: International Waterfowl Research Bureau (Publ. 29). 
Ruitenbeek, H. J. (1994) Modelling economy-ecology linkages in mangroves: economic evidence for promoting conservation in Bintuni Bay, Indonesia. Ecol. Econ. 10: 223-247.

Scott, D. A. (1989) A directory of Asian wetlands. Gland, Switzerland: The World Conservation Union.

Scott, D. A., Howes, J. R. and Le Dien Duc (1989) Recommendations for management of Xuan Thuy Reserve, Red River Delta, Vietnam. Kuala Lumpur: Asian Wetland Bureau (Publ. 44).

Sibley, C. G. and Monroe, B. L. (1990) Distribution and taxonomy of birts of the world. New Haven: Yale University Press.

Stusak, J. M. and Vo Quy (1986) The birds of the Hanoi area. Prague: University of Agriculture.

Wildash, P. (1968) Birds of Sotth Vietnam. Rutland, Vermont: Charles E. Tuttle.

ANITA PEDERSEN and SANNE SCHNELL NIELSEN

Zoological Museum, University of Copenhagen, Universitetsparken 15, DK-2100 Copenhagen $\varnothing$, Denmark.

LE DIEN THUY

Institute of Ecology and Biological Resources, Nationl Centre for Sciences and Technology, Nghia Do, Tu Liem. Hanoi, Vietnam.

\section{LE TRONG TRAI}

Forest Inventory and Planning Institute, Ministry of Agriculture and Rural Development, Thanh Tri, Hanoi, Vietnam. 